\title{
ASSOCIATION BETWEEN SLEEP CHARACTERISTICS AND MILD COGNITIVE IMPAIRMENT IN ELDERLY PEOPLE
}

\author{
Received March 29, 2013.
}

We compared the sleep quality indices between patients with mild cognitive impairment (MCI) and normal elderly subjects and analyzed the effects of sleep characteristics on cognitive functions. Cases of MCI patients (320 persons, MCI group) and 630 normal elderly with matched age, gender, and level of education (control group) were enrolled in this study. The Pittsburgh Sleep Quality Index (PSQI) was used to assess the sleep characteristics. The Mini-Mental State Examination (MMSE) and Montreal Cognitive Assessment (MoCA) were used to assess cognitive function. There were $110(34.3 \%)$ and $170(27 \%)$ cases with sleep disorders in the MCI and control groups, respectively $(P<0.01)$. There was a significant difference of total PQSI scores between the two groups, and the scores of sleep duration (factor III) and habitual sleep efficiency (factor IV) in the MCI group were significantly lower than those in the control group. Total PQSI scores negatively correlated with MoCA scores and MMSE scores. MoCA scores negatively correlated with scores of the sleep latency (factor II), sleep duration (factor III), and habitual sleep efficiency (factor IV), while MMSE scores negatively correlated with scores of factor III and factor IV. The scores of attention and calculation, reading and language understanding, and visuospatial function (MMSE), and also of visuospatial/executive function, attention, and clock-drawing test (MoCA) in MCI patients without sleep disorders were significantly higher than those in MCI patients with such disorders. The incidence of sleep disorders is higher in patients with MCI, compared with normal elderly. Effects of sleep disorders on cognitive functions are mainly reflected in the state of attention, and visuospatial/executive function.

Keywords: sleep, mild cognitive impairment, cognitive functions, Montreal Cognitive Assessment, Mini-Mental State Examination, Pittsburgh Sleep Quality Index

\section{INTRODUCTION}

With increase in age and appearance of age-related problems, the incidence of sleep disorders increases [1, 2]. Mild cognitive impairment (MCI) is a mild memory or cognitive dysfunction, which can be diagnosed but does not dramatically affect living abilities. It is a clinical status between normal aging and early dementia [3]; at the same time, it is considered an ultra-early stage of Alzheimer's disease (AD), with the risk of progressing to clear, clinically manifested $\mathrm{AD}$. In recent years, MCI has attracted more and more

\footnotetext{
${ }^{1}$ First Hospital of the Hebei Medical University, Shijiazhuang, China;

${ }^{2}$ Mental Health Institute of the Hebei Medical University, Shijiazhuang, China; ${ }^{3}$ Hebei Brain Ageing and Cognitive Neuroscience Laboratory, Shijiazhuang, China

Corresponding should be addressed to:

M. Wang (e-mail: mingweiwangcn@yeah.net)

or to X. Wang (e-mail: xueyiwanga@yeah.net_
}

attention. Researchers have found that sleep disorders are indicative of elderly cognitive impairment [4], and the cognitive decline in normal elderly is significantly associated with sleep disorders [5]. The sleep quality positively correlates with psychological test scores. The worse the sleep quality, the worse the test scores. Lack of sleep can lead to decline of rapid response ability and to impairment of executive functions [6, 7]. Positron emission tomography (PET) showed that there are metabolic declines in cerebral areas related to attention, information processing, and executive function in individuals with deprived sleep [8]. Functional magnetic resonance imaging (fMRI) showed that the state of cortical networks is associated with sustained attention, and sleep deprivation will disturb the function of these networks [9]. Sleep impairment affects visuospatial [10], auditory [11], tactile [12], and olfactory perception [13]. Sleep disorders can be considered a concomitant symptom of cognitive 
impairment. At the same time, decreased sleep quality can further aggravate cognitive impairment.

In our study, the sleep quality in MCI patients was assessed. The objective was to find an association between cognitive impairment and sleep disorders.

\section{METHODS}

General data. Following the cluster sampling method, a general questionnaire survey and cognitive function assessment were conducted on 1605 elderly ( $\geq 60$ years old) in six communities in Shijiazhuang, Tangshan, and Handan in Hebei, China, from December 2009 to December 2010. The examined groups included 320 MCI patients (MCI group) and 630 normal elderly with matched age, gender, and level of education.

In the MCI group, the inclusion criteria were as follows: (i) Memory impairment was the chief complaint (confirmed by relatives or insiders); objective examination showed memory impairment inconsistent with age and education level, with normal overall cognitive function and the ability to perform the activities of daily living; the patients did not meet the diagnostic criteria for dementia [14]. (ii) The ages were $\geq 60$ years. (iii) Patients could cooperate with the cognitive function test.

The exclusion criteria were as follows: (i) Patients could not cooperate with the cognitive function test due to aphasia, deafness, blindness, color blindness, or other physical deficiencies. (ii) Patients had neurological diseases causing clear brain dysfunctions, including acute stroke and Parkinson's disease. (iii) Patients had severe depression, schizophrenia, phrenitis, and clouding of consciousness, which impacted the cognitive function assessment. (iv) Patients had serious physical illnesses affecting sleep. There were 146 men and 174 women, with a mean age of $70 \pm 6$ years (mean \pm s. d.) and average $6 \pm 4$ years of education.

In the control group, the inclusion criteria were as follows: (i) The ages were not $\geq 60$ years. (ii) There was no chief complaint of cognitive dysfunction. (iii) According to the education level, the scores of MiniMental State Examination (MMSE) were higher than the delimitation, and the scores of Montreal Cognitive Assessment (MoCA) were not less than 26, with the scores of activity of daily living (ADL) less than 26. (iv) Subjects could cooperate with the cognitive function test. Exclusion criteria were the same as those in the MCI group. There were 302 men and
328 women, with a mean age of $70 \pm 6$ years and average $6 \pm 4$ years of education.

There were no significant differences in age $(F=2.07, P=0.35)$, gender $(F=4.39, P=0.11)$, and average level of education $(F=0.37, P=0.83)$ between the two groups.

Assessment of the cognitive function. All scale assessments were performed by trained psychiatrists (after training, the consistency test showed a Kappa of 0.83). The MoCA and MMSE were used for assessment of the state of the cognitive sphere. The items of MoCA included visuospatial function, memory, language fluency, and abstract thinking, with a total of 30 scores. For subjects with less than 12 years of education, one score was added to the test result to correct the bias of the education level. Higher scores represented better cognitive function. The delimitation score was 26 , and scores less than 26 were considered indicative of cognitive impairment [15].

The MMSE was commonly used in senile dementia screening, and its items included orientation, memory, and attention, with a total of 30 scores. It was more suitable for patients with moderate to severe dementia, and the sensitivity and specificity in distinguishing normal elderly from dementia patients was $80-90 \%$. Estimates of scores $<27$ (junior high school and above), $<24$ (primary school), and $<21$ (illiterate) represented cognitive function decline [16]. In the MCI group, the MoCA scores were less than 26, and the MMSE scores were higher than the delimitation according to different education levels.

Assessment of sleep quality. The sleep quality (overall sleep quality in the past one month) of subjects was assessed using the Pittsburgh Sleep Quality Index (PSQI). The PSQI consisted of 19 questions (e.g., during the past two weeks, how long had it usually taken the subject to fall asleep each night) and 7 subscales. Among the latter, there are subjective sleep quality (factor I), sleep latency (factor II), sleep duration (factor III), habitual sleep efficiency (factor IV), sleep disturbances (factor V), use of medication (factor VI), and daytime dysfunction (factor VII). Each factor was graded from 0 to 3 . The total PSQI scores represented the sum of the seven subscales and ranged from 0 to 21 . The PSQI did not ask about mood symptoms. In general, scores $\geq 5$ represented clear sleep problems $[17,18]$.

Statistical analysis. Original data were coded and managed by an independent database established by the Institute of Basic Medical Sciences and Institute of Clinical Medicine in the China Academy of 
Traditional Chinese Medicine. All data were entered by professional personnel at a double-entry mode to ensure correctness. After examination, verification, modification, and submission, SPSS 17.0 statistical software was used for statistical analysis. An independent sample $t$-test was conducted to analyze the differences of total PSQI scores and individual factor scores between the MCI and control groups. Pearson's correlation coefficient was used for analysis of MoCA, MMSE, and PSQI scores in all enrolled subjects.

\section{RESULTS}

Comparisons of the incidence of sleep disorders and PQSI scores. There were $110(34.3 \%)$ and 170 $(27 \%)$ cases with clear sleep disorders in the MCI and control groups, respectively, with a significant difference between them $(F=7.35, P=0.007)$. Total PQSI scores and individual factor scores in the two groups are shown in Table 1. There was significant difference of total PQSI scores between two groups
$(F=4.21, P=0.04)$. The scores of sleep duration (factor III) and habitual sleep efficiency (factor IV) in the MCI group were significantly lower than those in the control group $(F=6.90, P=0.00$ and $F=7.51$, $P=0.00$, respectively).

Correlations of PQSI scores with MoCA and MMSE scores. Correlations of total PQSI scores and individual factor scores with MoCA scores and MMSE scores are shown in Table 2. Total PQSI scores negatively correlated with MoCA scores and MMSE scores, respectively $(r=-0.12$ and $r=-0.09$, respectively). The MoCA scores negatively correlated with scores of the sleep latency (factor II), sleep duration (factor III), and habitual sleep efficiency (factor IV); $(r=-0.08, P=0.01 ; r=-0.09, P=0.00$, and $r=-0.14, P=0.00$, respectively). The MMSE scores were negatively correlated with scores of factor III and factor IV $(r=-0.09, P=0.00$ and $r=-0.12$, $P=0.00$, respectively).

General manifestations in MCI patients with and without sleep disorders. As shown in Table 3, there was no significant difference between the frequencies of cases of angina, hypertension, cerebral infarction,

Table 1. Total PQSI and individual factor estimates in MCI and control groups (scores, $\mathrm{M} \pm$ s.d.)

Таблиця 1. Сумарні оцінки та оцінки індивідуальних акторів за PQSI в групах MCI та контролю (бали, М \pm s.d.).

\begin{tabular}{c|c|c|c|c|c|c|c|c|c}
\hline Group & $\mathrm{n}$ & Total & Factor I & Factor II & Factor III & Factor IV & Factor V & Factor VI & Factor VII \\
\hline MCI & 320 & $6.11 \pm 4.29$ & $0.90 \pm 0.70$ & $1.20 \pm 1.16$ & $0.98 \pm 0.98$ & $0.81 \pm 1.06$ & $1.13 \pm 0.71$ & $0.25 \pm 0.07$ & $0.21 \pm 0.05$ \\
Control & 630 & $5.46 \pm 3.94$ & $0.94 \pm 0.76$ & $1.29 \pm 1.21$ & $1.14 \pm 1.06$ & $1.04 \pm 1.18$ & $1.18 \pm 0.87$ & $0.28 \pm 0.07$ & $0.25 \pm 0.06$ \\
& $F$ & 4.21 & 0.37 & 2.79 & 6.90 & 7.51 & 2.64 & 1.74 \\
& & 0.04 & 0.54 & 0.09 & 0.00 & 0.00 & 0.10 & 0.18 \\
\hline
\end{tabular}

Table 2. Correlations of the PQSI estimates with MoCA and MMSE scores

Таблиця 2. Кореляції оцінок за PQSI з бальними оцінками за МоСА та MMSE.

\begin{tabular}{|c|c|c|c|c|}
\hline \multirow{2}{*}{ PQSI scores } & \multicolumn{2}{|c|}{ MoCA } & \multicolumn{2}{|c|}{ MMSE } \\
\hline & $r$ & $P$ & $r$ & $P$ \\
\hline Total & -0.12 & 0.00 & -0.09 & 0.00 \\
\hline Factor I & -0.03 & 0.35 & -0.02 & 0.42 \\
\hline Factor II & -0.08 & 0.01 & -0.05 & 0.09 \\
\hline Factor III & -0.09 & 0.00 & -0.09 & 0.00 \\
\hline Factor V & -0.01 & 0.74 & 0.00 & 0.97 \\
\hline Factor VI & -0.06 & 0.03 & -0.06 & 0.07 \\
\hline Factor VII & -0.07 & 0.02 & -0.05 & 0.11 \\
\hline
\end{tabular}


Table 3. General pathological manifestations in MCI patients with and without sleep disorders

Таблиця 3. Загальні патологічні прояви у паціснтів групи МСI з розладами сну та без них.

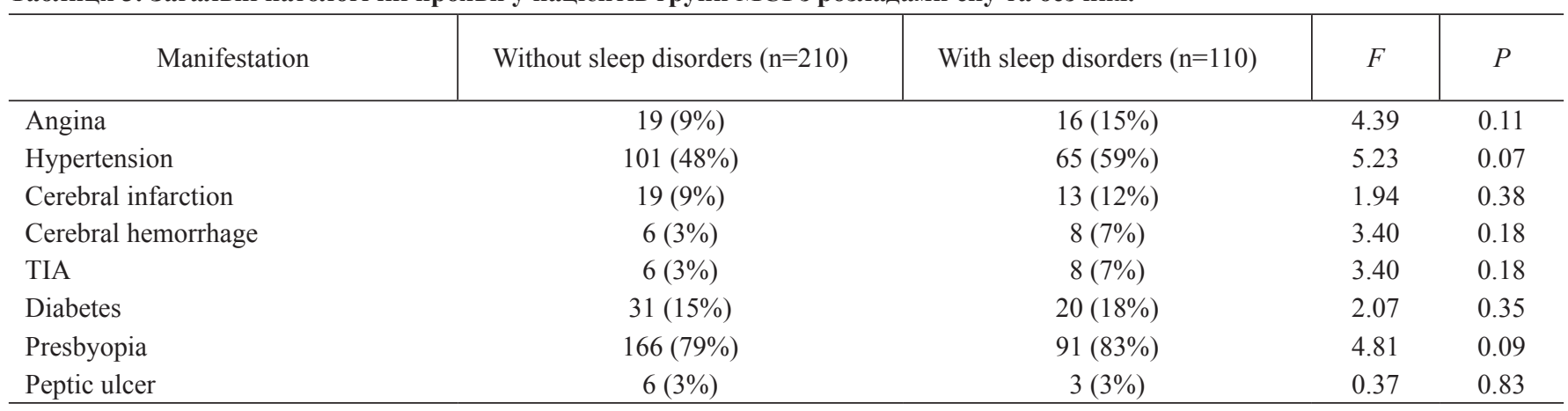

Footnote: Numbers of cases and normalized numbers (\%, in parentheses) are shown.

Table 4. Comparison of MMSE estimates between MCI patients with and without sleep disorders

Таблиця 4. Порівняння оцінок за MMSE у паціснтів групи МСI з розладами сну та без них.

\begin{tabular}{|c|c|c|c|c|}
\hline Total & $26.39 \pm 2.40$ & $26.01 \pm 2.54$ & 1.79 & 0.07 \\
\hline Location orientation & $4.92 \pm 0.28$ & $4.91 \pm 0.34$ & 0.55 & 0.58 \\
\hline Immediate recall & $2.84 \pm 0.43$ & $2.86 \pm 0.38$ & -0.38 & 0.70 \\
\hline Attention and calculation & $3.93 \pm 1.17$ & $3.69 \pm 1.27$ & 2.18 & 0.03 \\
\hline Recapitulation & $0.67 \pm 0.47$ & $0.66 \pm 0.47$ & 0.35 & 0.72 \\
\hline Language understanding & $2.94 \pm 0.25$ & $2.92 \pm 0.32$ & 0.85 & 0.39 \\
\hline $\begin{array}{l}\text { Reading and language } \\
\text { understanding }\end{array}$ & $0.92 \pm 0.28$ & $0.85 \pm 0.36$ & 2.32 & 0.02 \\
\hline Writing & $0.53 \pm 0.50$ & $0.54 \pm 0.50$ & -0.17 & 0.86 \\
\hline
\end{tabular}

Table 5. Comparison of MoCA estimates between MCI patients with and without sleep disorders

Таблиця 5. Порівняння оцінок за МоСА у пацієнтів групи МСI з розладами сну та без них.

\begin{tabular}{|c|c|c|c|c|}
\hline Total & $21.35 \pm 3.28$ & $20.44 \pm 3.57$ & 3.06 & 0.00 \\
\hline Naming & $2.79 \pm 0.47$ & $2.71 \pm 0.51$ & 1.71 & 0.09 \\
\hline Attention & $4.99 \pm 1.02$ & $4.74 \pm 1.14$ & 2.61 & 0.00 \\
\hline Abstract thinking & $0.76 \pm 0.77$ & $0.72 \pm 0.74$ & 0.52 & 0.60 \\
\hline Delayed recall & $1.68 \pm 1.33$ & $1.58 \pm 1.33$ & 0.84 & 0.40 \\
\hline Orientation & $5.56 \pm 0.66$ & $5.50 \pm 0.70$ & 0.89 & 0.37 \\
\hline Clock-drawing test & $2.29 \pm 0.90$ & $2.08 \pm 0.94$ & 2.50 & 0.01 \\
\hline
\end{tabular}


cerebral hemorrhage, transient ischemia attack (TIA), diabetes, presbyopia, and peptic ulcer between MCI patients with and without sleep disorders. The age and years of education in MCI patients with sleep disorders matched those in MCI patients without sleep disorders.

Comparison of the MMSE scores between MCI patients with and without sleep disorders. Comparison of total MMSE scores and individual factor scores between MCI patients with and without sleep disorders are shown in Table 4. There was no significant difference in total MMSE scores between MCI patients with and without the above disorders. The attention and calculation, reading and language understanding, and visuospatial function scores in MCI patients without sleep disorders were significantly higher than those in MCI patients with sleep disorders $(t=2.18, P=0.03 ; t=2.32, P=0.02$, and $t=2.31$, $P=0.02$, respectively), with no significant differences in other factor scores between two groups.

Comparison of the MoCA scores. As shown in Table 5, the total MoCA scores in MCI patients without sleep disorders were significantly greater than those in patients with sleep disorders $(t=3.06$, $P=0.00)$. Comparisons of individual factor scores showed that the visuospatial and executive functions, attention, and clock-drawing test scores in patients without sleep disorders were significantly higher than those in patients with the mentioned disorders $(t=3.23, P=0.00 ; t=2.61, P=0.00$, and $t=2.50$, $P=0.01$, respectively).

\section{DISCUSSION}

In our study, the incidence of sleep disorders and the effects of sleep quality on cognitive functions have been assessed. We found that, compared with normal elderly, MCI patients have noticeably more sleep problems. The effects of sleep disorders on cognitive functions are mostly reflected in the state of attention and reading and language understanding.

It was found that patients with dementia have obvious sleep rhythm disorders [19], and the incidence of sleep disorders in AD patients is $25-44 \%$ [20]. The MCI is considered an early symptom or a high-risk factor for dementia, especially for AD [21]. There is a higher risk of $\mathrm{AD}$ or other types of dementia in MCI patients with sleep disorders [22]. MCI, similarly to dementia, is influenced by risk factors including age, educational level, physical exercise, and sleep disorders. The incidence of sleep disorders in patients with dementia was found to be higher than that in normal elderly. The main manifestations include obvious sleep-wake rhythm impairment, low sleep efficiency, a lower percentage of rapid eye movements (REMs) within the sleep period, frequent awakening, and shallow sleep [23]. The findings of our study are consistent with those of previous publications. These facts show that cerebral systems responsible for the sleep/wake cycle are mildly but noticeably impaired in a significant proportion of MCI patients.

The MMSE test combined with MoCA is adopted to assess the state of cognitive function in the examined subjects. The MoCA was proposed by Nasreddine et al. [15] in Canada according to clinical experiences and cognitive items and scoring methods of MMSE. It is a rapid screening tool for detecting cognitive impairment, including 11 detection items in 8 areas, attention and concentration, executive functions, memory, language, visuospatial function, abstract thinking, calculation, and orientation. The total score is 30 , and scores $\geq 26$ represent the normal state. Due to a higher sensitivity, wide coverage range, and short testing time, MoCA is more suitable for clinical use. In addition, MoCA is more sensitive in MCI screening compared to MMSE and can be used for screening MCI patients with normal MMSE scores. An MMSE score value higher than delimitation is the criterion for MCI MMSE. The cognitive impairment in patients with MoCA scores lower than delimitation (26 scores) is milder than that with MMSE screening. Even so, the total PSQI scores in these patients are significantly different from the control. This indicates that the sleep quality in MCI patients is much lower than that in normal elderly, especially for the sleep duration and habitual sleep efficiency. There were no significant differences in factor I, II, V, VI, and VII scores between the two groups.

It should be recognized that coefficients of correlation between the examined indices calculated in our study are relatively low. Thus, the respective correlations are not strong and indicative of only some trends but not of strong dependences. Nonetheless, these correlations, due to the sufficiently large number of subjects in the examined groups, are quite significant.

As found in a previous study, low sleep quality will affect cognitive functions (such as learning and memory) in patients with MCI [24]. In this study, both MMSE and MoCA scores were found to negatively correlate with the total PSQI score, especially for MoCA scores negatively correlating with the scores 
of PSQI factors II, III, and IV. This indicates that poor sleep quality can also be a factor causing decline of cognitive functions.

It was also found that, compared with MCI patients without sleep disorders, the cognitive impairment in MCI patients with such disorders is mainly reflected in deficiencies of attention and visuospatial/executive functions. As was shown in previous studies, the prefrontal cortex may be more sensitive to lack of sleep $[25,26]$. This lack can lead to significant metabolic disorders in the brain, especially in the prefrontal cortex [27]. The prefrontal cortex is closely related to executive functions, especially to highgrade ones. It is believed that there is an apparent connection between functional characteristics of the prefrontal cortex and those of the sleep/wake system [28-30]. In addition, lack of sleep may cause a decline in executive function [31]. Manly et al. [32] found that sleep deprivation causes visuospatial impairment. In particular, lack of sleep mainly affects the right hemisphere, but this viewpoint is not widely accepted. A study on patients with multiple sclerosis [33] showed that sleep problems can lead to a sustained decrease in attention. In patients with the attention deficit / hyperactivity disorder (ADHD), inattention is associated with insomnia [34].

In our study, the total PSQI scores in the MCI group exceeded 6, while those in normal elderly were more than 5. This indicates that the sleep quality in persons older than 60 years gradually decreases, and that sleep disorders are a widespread phenomenon that merits our great attention. Of course, the assessment of sleep disorders in the elderly using the PSQI may be affected by some subjective factors. Multichannel EEG studies may provide more clinical significance. The limitations of our study are as follows: (i) The causes of sleep disorders have not been subdivided; these causes included breathing-related sleep disorders, restless legs syndrome, and periodic leg movements. (ii) Multichannel EEG and video polysomnography have not been used for the diagnosis of sleep disorders.

It, however, should be taken into account that these techniques are relatively complex and expensive so they cannot be successfully applied for examination of large populations.

This study was conducted in accordance with the Declaration of Helsinki. The study was conducted with approval from the Ethics Committee of the First Hospital of the Hebei Medical University. Written informed consent was obtained from all participants.
The authors of the report, C. An, L. Yu, L. Wang, G. Jin, M. Song, Q. Zhu, H. Jia, K. Liu, M. Wang, and X. Wang, have no conflict of interest.

Acknowledgement. This work was supported by the Science and Technology Support Program of Hebei Province (No. 09276103D).

$$
\begin{aligned}
& \text { К. } A \mu^{1,2}, \text { Л. Ю }{ }^{1,2}, \text { Л. Ван }{ }^{1,2} \text { Г. Джін }{ }^{1,2}, \text { М. Сонг }{ }^{1,2}, \text { К. Жу } y^{1,2} \text {, } \\
& \text { Х. Джіа }{ }^{1,2} \text { K. Лю }{ }^{1,2} \text { M. Baн }{ }^{1,3}, \text { Kс. Baн }{ }^{1,2}
\end{aligned}
$$

ЗВ' ЯЗКИ МІЖ ХАРАКТЕРИСТИКАМИ ПРОЦЕСУ СНУ ТА ПОМІРНИМИ ПОРУШЕННЯМИ КОГНІТИВНИХ ФУНКЦІЙ У ЛЮДЕЙ ПОХИЛОГО ВІКУ

\footnotetext{
${ }^{1}$ Перша лікарня Медичного університету Хебей, Шіджіахуан (Китай).

2 Інститут розумового здоров'я Медичного університету Хебей, Шіджіахуан (Китай).

${ }^{3}$ Хебейська лабораторія старіння мозку та когнітивних нейрофункцій, Шіджіахуан (Китай).
}

P е 3 ю м е

Ми порівнювали показники якості сну у пацієнтів з помірними когнітивними порушеннями (MCI) та літніх людей без таких розладів і аналізували впливи характеристик процесу сну на когнітивні функції. У дослідженні брали участь 320 пацієнтів групи MCI та 630 здорових літніх людей контрольної групи, в яких співпадали вік, стать та рівень освіти. Для оцінки якості сну використовували Пітсбургський індекс якості сну PSQI, а для оцінки статусу когнітивної сфери - системи MMSE та MoCA. У групах MCI та контролю було $110(34.3 \%)$ та 170 (27\%) випадків розладів сну $(P<0.01)$. Сумарні значення оцінок PSQI демонстрували вірогідні міжгрупові відмінності; оцінки тривалості сну (фактор III) та звичайної ефективності сну (фактор IV) у групі MCI були вірогідно нижчими, ніж у контрольній групі. Загальні оцінки PSQI негативно корелювали з оцінками за шкалами MoCA та MMSE. Оцінки за МоCA негативно корелювали зі значеннями латентного періоду сну (фактор II), тривалості сну (фактор III) та звичайної ефективності сну (фактор IV), тоді як оцінки за MMSE знаходились у негативній кореляції з бальними оцінками факторів III та IV. Бальні оцінки за шкалами уваги, кількісних розрахунків, розуміння читання й мовлення та просторово-зорової функції за MMSE, а також просторово-зорової/виконавчої функції, уваги та тесту з малювання годинника за МоCA у пацієнтів групи МCI без розладів сну були істотно більшими, ніж відповідні значення у МСІ-пацієнтів з такими розладами. Таким чином, частота розладів сну у пацієнтів із помірними розладами когнітивної сфери є вищою, ніж така у здорових літніх осіб. Впливи розладів сну на когнітивні функції в основному відображуються в розладах уваги та просторово-зорової/виконавчої функції. 


\section{REFERENCES}

1. S. Ancoli-Israel and L. Ayalon, "Diagnosis and treatment of sleep disorders in older adults," Am. J. Geriat. Psychiat., 14, 95-103 (2006).

2. C. Stepnowsky and S. Ancoli-Israel, "Sleep and its disorders in seniors," Sleep Med. Clin., 3, 281-293 (2008).

3. J. M. Ringman, L. D. Medina, Y. Rodriguez-Agudelo, et al., "Current concepts of mild cognitive impairment and their applicability to persons at risk for familial Alzheimer's disease," Current Alzheimer Res., 6, 341-346 (2009).

4. M. Jelicic, H. Bosma, R. W. Ponds, et al., "Subjective sleep problems in later life as predictors of cognitive decline. Report from the Maastricht Ageing Study (MAAS)," Int. J. Geriat. Psychiat., 17, 73-77 (2002).

5. C. Sutter, J. Zöllig, M. Allemand, and M. Martin, "Sleep quality and cognitive function in healthy old age: the moderating role of subclinical depression," Neuropsychology, 26, 768 -775 (2012).

6. S. M. Doran, H. P. Van Dongen, and D. F. Dinges, "Sustained attention performance during sleep deprivation: Evidence of state instability," Arch. Ital. Biol., 139, 253-267 (2001).

7. H. P. Van Dongen, G. Maislin, J. M. Mullington, and D. F. Dinges, "The cumulative cost of additional wakefulness: Dose-response effects on neurobehavioral functions and sleep physiology from chronic sleep restriction and total sleep deprivation," Sleep, 26, 117-126 (2003).

8. M. Thomas, H. Sing, G. Belenky, et al., "Neural basis of alertness and cognitive performance impairments during sleepiness. I. Effects of $24 \mathrm{~h}$ of sleep deprivation on waking human regional brain activity," J. Sleep Res., 9, 335-352 (2000).

9. S. P. Drummond, A. Bischoff-Grethe, D. F. Dinges, et al., "The neural basis of the psychomotor vigilance task," Sleep, 28 , 1059-1068 (2005)

10. W. D. Killgore, A. P. Kendall, J. M. Richards, and S. A. McBride, "Lack of degradation in visuospatial perception of line orientation after one night of sleep loss," Percept. Mot. Skills, 105, 276-286 (2007).

11. H. Babkoff, G. Zukerman, L. Fostick, and E. Ben-Artzi, "Effect of the diurnal rhythm and $24 \mathrm{~h}$ of sleep deprivation on dichotic temporal order judgment," J. Sleep Res., 14, 7-15 (2005).

12. M. Haack, E. Lee, D. A. Cohen, and J. M. Mullington, "Activation of the prostaglandin system in response to sleep loss in healthy humans: Potential mediator of increased spontaneous pain," Pain, 145, 136-141 (2009).

13. W. D. Killgore, and S. A. McBride, "Odor identification accuracy declines following $24 \mathrm{~h}$ of sleep deprivation," J. Sleep Res., 25, 111-116 (2005).

14. R. C. Petersen, G. E. Smith, S. C. Waring, et al., "Mild cognitive impairment: clinical characterization and outcome," Arch. Neurol., 56, 303-308 (1999).

15. Z. S. Nasreddine, N. A. Phillips, V. Bédirian, et al., "The Montreal Cognitive Assessment, MoCA: a brief screening tool for mild cognitive impairment," J. Am. Geriat. Soc., 53, 695699 (2005).
16. R. C. Petersen, "Mild cognitive impairment as a diagnostic entity," J. Intern. Med., 256, 183-194 (2004).

17. D. J. Buysse, C. F. Reynolds, T. H. Monk, et al., "The Pittsburgh Sleep Quality Index: a new instrument for psychiatric practice and research," Psychiat. Res., 28, 193-213 (1998).

18. D. J. Buysse, C. F. Reynolds 3rd, T. H. Monk, et al., "Quantification of subjective sleep quality in healthy elderly men and women using the Pittsburgh Sleep Quality Index (PSQI)," Sleep, 14, 331-338 (1991).

19. Y. L. Huang, R. Y. Liu, Q. S. Wang, et al., "Age-associated difference in circadian sleep-wake and rest-activity rhythms," Physiol. Behav., 76, 597-603 (2002).

20. M. V. Vitiello and S. Borson, "Sleep disturbances in patients with Alzheimer's disease: epidemiology, pathophysiology and treatment," CNS Drugs, 15, 777-796 (2001).

21. S. Gauthier, B. Reisberg, M. Zaudig, et al., "Mild cognitive impairment," Lancet, 367, 1262-1270 (2006).

22. J. F. Gagnon, M. Vendette, R. B. Postuma, et al., "Mild cognitive impairment in rapid eye movement sleep behavior disorder and Parkinson's disease," Ann. Neurol., 66, 39-47 (2009).

23. D. L. Bliwise, "Sleep disorders in Alzheimer's disease and other dementias," Clin. Cornerstone, 6, S16-28 (2004).

24. C. E. Westerberg, E. M. Lundgren, S. M. Florczak, et al., "Sleep influences the severity of memory disruption in amnestic mild cognitive impairment: results from sleep selfassessment and continuous activity monitoring," Alzheimer Dis. Assoc. Disord., 24, 325-333 (2010).

25. Y. Harrison, J. A. Horne, and A. Rothwell, "Prefrontal neuropsychological effects of sleep deprivation in young adults - a model for healthy aging?" Sleep, 23, 1067-1073 (2000).

26. K. Jones and Y. Harrison, "Frontal lobe function, sleep loss and fragmented sleep," Sleep Med. Rev., 5, 463-475 (2001).

27. W. D. Killgore, "Effects of sleep deprivation on cognition," Prog. Brain Res., 185, 105-129 (2010).

28. A. R. Braun, T. J. Balkin, N. J. Wesenten, et al., "Regional cerebral blood flow throughout the sleep-wake cycle. An H2(15)O PET study," Brain, 120, 1173-1197 (1997).

29. J. S. Durmer and D. F. Dinges, "Neurocognitive consequences of sleep deprivation," Semin. Neurol., 25, 117-129 (2005).

30. K. Jones and Y. Harrison, "Frontal lobe function, sleep loss and fragmented sleep," Sleep Med. Rev., 5, 463- 475 (2001).

31. R. D. Nebes, D. J. Buysse, E. M. Halligan, et al., "Selfreported sleep quality predicts poor cognitive performance in healthy older adults," J. Geront. Psychol. Sci. Soc. Sci., 64, 180-187 (2009).

32. T. Manly, V. B. Dobler, C. M. Dodds, and M. A. George, "Rightward shift in spatial awareness with declining alertness," Neuropsychology, 43, 1721-1728 (2005).

33. P. Lehmann, P. Eling, A. Kastrup, et al., "Self-reported sleep problems, but not fatigue, lead to decline in sustained attention in MS patients," Mult. Scler., 19, 490-497 (2012).

34. S. J. Kass, J. C. Wallace, and S. J. Vodanovich, "Boredom proneness and sleep disorders as predictors of adult attention deficit scores," J. Atten. Disord., 7, 83-91 (2003). 